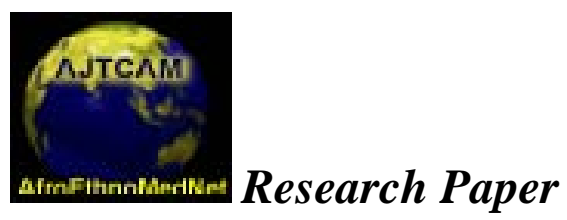

Afr. J. Infect. Diseases

www.africanethnomedicines.net

\title{
ASSESSMENT OF RENAL FUNCTION IN MALARIA PATIENTS IN MINNA, NORTH CENTRAL NIGERIA
}

\section{Emmanuel O. Ogbadoyi ${ }^{{ }^{*}}$ and Baba Gabi ${ }^{2}$}

${ }^{1}$ Department of Biochemistry, Federal University of Technology, Bosso Road, Minna, Nigeria.

${ }^{2}$ Present address: Department of Applied Sciences, College of Science and Technology, Kaduna

Polytechnic, Kaduna, Nigeria.

*E-mail: eogbadoyi@yahoo.com

\begin{abstract}
Establishment of prevalence of malaria-associated renal impairment in Nigeria is important for proper prognosis and management of malaria and its associated complications. Using biuret method for protein estimation, alkaline picrate-slot method for creatinine and urea estimation, and flame photometry and titrimetric method for electrolytes estimation, selected kidney function parameters which included proteinuria, serum levels of urea, creatinine and electrolytes were determined in 169 malaria patients and in 58 individuals without malaria. Data obtained were analyzed using one-way analysis of variance to compare variation among malaria patients and individuals without malaria, Duncan multiple range test to compare variation among means, and correlation matrix to evaluate correlation between the parameters measured. Proteinuria in malaria cases differed significantly $(p<0.05)$ from individuals without malaria, and a positive correlation existed between proteinuria and parasitaemia. There was no significant difference $(p>0.05)$ in the creatinine levels of malaria patients and those without malaria. It is concluded that there is a form of renal impairment associated with malaria infection in Minna irrespective of age and sex.
\end{abstract}

Key words: Malaria, Renal function, Assessment, ARF

\section{Introduction}

Malaria is a life threatening disease with nearly half of the world population being vulnerable to infection (Mishra et al., 2002). Malaria accounts for an estimated 2-3 million deaths annually and it is also responsible for untold morbidity in approximately 300-500 million people annually (Mishra et al., 2002). Malaria is caused by plasmodium, which is transmitted by mosquitoes. Four species of plasmodium cause malaria in humans. These are Plasmodium falciparume, $P$. vivax, $P$ malariae and P. ovale. $P$. falciparum is responsible for most deaths and most of the severe complications (Nchinda, 1998), including cerebral malaria, anemia and renal failure (Kocha et al., 2003).

Serious cases of renal problems associated with malaria take the form of nephritic syndrome, which gradually progress to renal failure (Rees et al 19972; Edward and Bouchier 1991). It is characterized by severe proteinuria (Rees et al 1972; Rui-mei et al 1998b; Obgadoyi and Tembeng 1999, Sinnah et al 1999), rise in blood urea, low urine specific gravity, low ratio of urinary to blood urea (Vanvelthuysen,1996) and hyper-kalaemia and metabolic acidosis (Mishra et al, 2002). ARF occurs in about $60 \%$ of all cases of complicated malaria (Boonpucknavig and Sitprija, 1979; Sitprija, 1988; Nanda et al, 2004). In Plasmodium falciparum malaria, ARF occurs in 1-5\% of cases (Sheehy and Reba, 1967; Prakash et al., 1996; Naqvi et al., 2003) with mortality of $15-45 \%$ (Barsoum, 2000)

Considering the endemicity of malaria in Nigeria, the mortality and morbidity rate across families, particularly in children and pregnant women, accurate prognosis and proper management are very 
necessary. The incidence of kidney problems is on the increase in Nigeria. Malaria and other infectious diseases may be contributing factors. It is therefore important to know the prevalence level of renal involvement in malaria cases to ensure effective management of the patients as they report to medical centres. This is important because in the presence of ARF, death increases three-fold, but with early detection and institution of frequent dialysis, mortality rate is reduced by $90 \%$ (Mishra, 2002). The severity of malaria associated renal impairment in a particular area is largely a function of the disease prevalence and other aetiological factors prevailing in the area (Naqvi et al., 2003). Unfortunately not much has been done to establish the degree of renal involvement in malaria cases in Nigeria, and Minna in particular. This study is a modest attempt to address this problem. We report here that there is some form of kidney disease associated with malaria infection in Minna, North Central Nigeria.

\section{Materials and Methods. \\ Urine samples}

Early morning urine samples were collected from malaria patients (individuals tested positive microscopically for malaria parasites) visiting Minna General hospital and the Federal University of Technology, Minna clinic. Control samples were similarly collected from apparently healthy individuals (without malaria parasite).

\section{Blood samples}

Using sterile syringes and needles venous blood samples from the patients and healthy individuals were collected. Samples were centrifuged and the sera collected for analysis.

\section{Study Population}

Male and female malaria patients of different age groups and apparently healthy non-malaria individuals (controls) were studied. The sampled population was classified into two age categories. These were ages 2-15 and ages 16 and above. The authors obtained verbal consent from the subjects. The patients were confirmed to have malaria by detection of malaria parasites in the blood smears prepared from their blood samples. A total of 260 individuals, made up of 146 males and 114 females, were investigated. 43 males and 15 females were controls while 103 males and 99 females were malaria patients.

\section{Methods}

Protein estimation

Protein concentrations in urine of malaria patients and healthy individuals were estimated by biuret method (Dittebrandt, 1948).

\section{Creatinine estimation}

Creatinine was estimated using the alkaline picrate-slot method (Cheesbrough, 1991a)

\section{Urea estimation}

Serum urea levels were estimated according to the method of Cheesbrough (1991b).

\section{Estimation of electrolyte levels}

$\mathrm{Na}^{+}$and $\mathrm{K}^{+}$. Sodium and potassium levels were estimated using flame photometry as described by Davidson and Henry (1979).

$\mathrm{HCO}_{3}{ }^{-}$and $\mathrm{Cl}^{-}$. Bicarbonate and chloride levels were estimated using titrimetric method of Davidson and Henry (1979). 


\section{Statistical analysis}

One-way ANOVA was used for variation analysis amongst healthy individuals and malaria patients while means were compared using Duncan multiple range test. Correlation coefficient was used to show correlation of the parameters measured.

\section{Results \\ Urinary protein level}

Results obtained showed that $72.2 \%$ (13 out of 18 ) of the 18 male children malaria patients had urinary protein level (mean $24.7 \pm 4.06$ ) well above the normal level of $15 \mathrm{mg} / \mathrm{dL}$, while $68.2 \%$ (58 out of 85 ) of male adult patients had urinary protein levels (mean: $23.69 \pm 1.64$ ) above the normal value (Table 1 ). These vary significantly $(\mathrm{P}<0.05)$ from the mean value $(12.00 \pm 0.72)$ of the healthy individuals (Figure 1$)$. Similarly, $82.4 \%$ (14 out of 17) of the female malaria children and $61.2 \%$ (30 out of 49) of non-pregnant women, and $63.6 \%$ (21 out of 33) of pregnant women patients had proteinuria levels well above the normal level (Table 1), which also differed significantly from the values of the healthy individuals (mean: $14.68 \pm$ 1.60). Correlation matrix indicated a positive correlation between urinary protein levels and parasitaemia.

\section{Serum creatinine level}

Statistical analysis showed there was no significant difference between the serum creatinine levels of all malaria patients examined and the healthy individuals. However, considerable percentage of patients had creatinine levels outside the normal range of 72 to $126 \mu \mathrm{mol} / 1$ (Table 1).

\section{Serum urea levels}

In males, including ages 2-15 and ages 16 and above, there was no significant difference in serum urea levels of non-malarial infected individuals and malarial patients. In females however, there was significant difference between the serum urea levels of malaria patients and individuals without malaria. A considerable percentage of the patients had levels, which were outside the normal range of 3.0 to $6.6 \mathrm{mmol} / 1$ (Table 1).

The table shows the normal ranges of the parameters measured the number of patients and the percentage the number represents, which have values greater or lower than the normal ranges. Values for the controls are also shown. Mean value \pm standard deviation of each parameter is indicated for each group - Controls (male and female), Patients (children - male and female, adults - male and female (pregnant and nonpregnant). numbers in bracket $=$ percentage of number of patients.

\section{Serum electrolyte levels}

Serum levels of four electrolytes, $\mathrm{Na}^{+}, \mathrm{K}^{+}, \mathrm{HCO}_{3}{ }^{-}$and $\mathrm{Cl}^{-}$were estimated in malaria patients and individuals without malaria. For sodium, there was no significant difference $(p>0.05)$ between the levels in male malaria patients and individuals without malaria. However in females, there was significant variation $(p<0.05)$ in sodium levels of all female categories of malaria patients and the controls. The reverse was the case with potassium in which significant difference existed $(\mathrm{p}<0.05)$ in potassium levels in all categories of male malaria patients and the levels in the control individuals but not so in females (Table 2). For bicarbonate, the difference in serum levels between control individuals and malaria patients was significant only in male children. There was no significant difference $(\mathrm{p}>0.05)$ in chloride levels between the controls and all cases examined. 
Table 1. Analysis of serum levels of protein, urea, and creatinine in malaria patients

\begin{tabular}{|c|c|c|c|c|c|c|c|c|}
\hline \multirow[t]{3}{*}{$\begin{array}{l}\text { Parameters \& } \\
\text { Normal values }\end{array}$} & \multicolumn{2}{|c|}{ Control } & & \multicolumn{4}{|c|}{ Patients } & \\
\hline & $\begin{array}{l}\text { Male } \\
\mathrm{N}=43\end{array}$ & $\begin{array}{l}\text { Female } \\
\mathrm{N}=15\end{array}$ & & \multicolumn{2}{|c|}{ Children } & \multicolumn{2}{|c|}{ Adults } & \\
\hline & $\begin{array}{l}\text { Mean } \\
\pm \mathrm{SD}\end{array}$ & $\begin{array}{l}\text { Mean } \\
\pm \mathrm{SD}\end{array}$ & & $\begin{array}{l}\text { Male } \\
\mathrm{N}=18\end{array}$ & $\begin{array}{l}\text { Female } \\
\mathrm{N}=17\end{array}$ & $\begin{array}{l}\text { Male } \\
\mathrm{N}=85\end{array}$ & Female & \\
\hline & & & & & & & $\begin{array}{l}\text { Non } \\
\text { Pregnant } \\
\mathrm{N}=49\end{array}$ & $\begin{array}{l}\text { Pregnant } \\
\mathrm{N}=33\end{array}$ \\
\hline & & & & $\begin{array}{l}\text { No. of } \\
\text { patients }\end{array}$ & $\begin{array}{l}\text { No. of } \\
\text { patients }\end{array}$ & $\begin{array}{l}\text { No. of } \\
\text { patients }\end{array}$ & $\begin{array}{l}\text { No. of } \\
\text { patients }\end{array}$ & $\begin{array}{ll}\text { No. } & \text { of } \\
\text { patients }\end{array}$ \\
\hline \multirow{3}{*}{$\begin{array}{l}\text { Protein } \\
0-15 \mathrm{mg} / \mathrm{dl}\end{array}$} & $\begin{array}{l}12.00 \\
\pm 0.72\end{array}$ & $\begin{array}{l}14.68 \\
\pm 1.60\end{array}$ & $>15 \mathrm{mg} / \mathrm{dl}$ & $\begin{array}{l}13 \\
(72.2)\end{array}$ & $\begin{array}{l}14 \\
(82.4)\end{array}$ & $\begin{array}{l}58 \\
(68.2)\end{array}$ & $\begin{array}{l}30 \\
(61.2)\end{array}$ & $\begin{array}{l}21 \\
(63.5)\end{array}$ \\
\hline & & & $\leq 15 \mathrm{mg} / \mathrm{dl}$ & $5(27.8)$ & $\begin{array}{l}3 \\
(17.6)\end{array}$ & $\begin{array}{l}27 \\
(31.8) \\
\end{array}$ & $\begin{array}{l}19 \\
(38.8) \\
\end{array}$ & $\begin{array}{l}12 \\
(36.4) \\
\end{array}$ \\
\hline & & & $\begin{array}{l}\text { Mean } \\
\pm \mathrm{SD} \\
\end{array}$ & $\begin{array}{l}24.79 \\
\pm 4.06 \\
\end{array}$ & $\begin{array}{l}33.87 \\
\pm 6.48 \\
\end{array}$ & $\begin{array}{l}23.67 \\
\pm 1.64 \\
\end{array}$ & $\begin{array}{l}23.2 \\
\pm 2.19 \\
\end{array}$ & $\begin{array}{l}24.62 \\
\pm 2.13 \\
\end{array}$ \\
\hline \multirow{4}{*}{$\begin{array}{l}\text { Urea } \mathrm{mMol} / 1 \\
3.0-6.6\end{array}$} & $\begin{array}{l}4.96 \\
\pm 0.22 \\
\end{array}$ & $\begin{array}{l}4.91 \\
\pm 0.05\end{array}$ & $\begin{array}{l}>6.6 \\
\mathrm{mmol} / \mathrm{l}\end{array}$ & $\begin{array}{l}5 \\
(27.8)\end{array}$ & $\begin{array}{l}6 \\
(35.3)\end{array}$ & $\begin{array}{l}16 \\
(18.8)\end{array}$ & $\begin{array}{l}4 \\
(8.2)\end{array}$ & $\begin{array}{l}3 \\
(9.1)\end{array}$ \\
\hline & & & $<3.0$ & $\begin{array}{l}8 \\
(44.4)\end{array}$ & $\begin{array}{l}2 \\
(11.6)\end{array}$ & $\begin{array}{l}12 \\
(14.1)\end{array}$ & $\begin{array}{l}17 \\
(34.7)\end{array}$ & $\begin{array}{l}10 \\
(30.3)\end{array}$ \\
\hline & & & Normal & $\begin{array}{l}5 \\
(27.8)\end{array}$ & $\begin{array}{l}9 \\
(52.9)\end{array}$ & $\begin{array}{l}57 \\
(67.1)\end{array}$ & $\begin{array}{l}28 \\
(57.1)\end{array}$ & $\begin{array}{l}20 \\
(60.6)\end{array}$ \\
\hline & & & $\begin{array}{l}\text { Mean } \\
\pm \text { SD }\end{array}$ & $\begin{array}{l}4.39 \\
\pm 0.56\end{array}$ & $\begin{array}{l}5.54 \\
\pm 0.79\end{array}$ & $\begin{array}{l}5.26 \\
\pm 0.35\end{array}$ & $\begin{array}{l}3.99 \\
\pm 0.26\end{array}$ & $\begin{array}{l}3.57 \\
\pm 0.27\end{array}$ \\
\hline \multirow[t]{4}{*}{$\begin{array}{l}\text { Creatinine } \\
\mu \mathrm{Mol} / 1 \\
72.0-126.0\end{array}$} & $\begin{array}{l}108.40 \\
\pm 2.80\end{array}$ & $\begin{array}{l}109.98 \\
\pm 6.31 \\
\end{array}$ & $\begin{array}{l}>126 \\
\mu \mathrm{mol} / 1\end{array}$ & $\begin{array}{l}4 \\
(22.2)\end{array}$ & $\begin{array}{l}6 \\
(35.3)\end{array}$ & $\begin{array}{l}22 \\
25.1\end{array}$ & $\begin{array}{l}5 \\
(10.2)\end{array}$ & $\begin{array}{l}5 \\
(15.2)\end{array}$ \\
\hline & & & $<72$ & $\begin{array}{l}1 \\
(5.6)\end{array}$ & $\begin{array}{l}0 \\
(0)\end{array}$ & $\begin{array}{l}4 \\
(4.7) \\
\end{array}$ & $\begin{array}{l}3 \\
(6.1) \\
\end{array}$ & $\begin{array}{l}3 \\
(9.1) \\
\end{array}$ \\
\hline & & & Normal & $\begin{array}{l}13 \\
(72.2) \\
\end{array}$ & $\begin{array}{l}11 \\
(64.7) \\
\end{array}$ & $\begin{array}{l}59 \\
(70.2) \\
\end{array}$ & $\begin{array}{l}41 \\
(83.7) \\
\end{array}$ & $\begin{array}{l}25 \\
(75.7) \\
\end{array}$ \\
\hline & & & $\begin{array}{l}\text { Mean } \\
\pm \mathrm{SD}\end{array}$ & $\begin{array}{l}103.44 \\
\pm 7.21\end{array}$ & $\begin{array}{l}119.59 \\
\pm 11.76\end{array}$ & $\begin{array}{l}115.76 \\
\pm 4.01\end{array}$ & $\begin{array}{l}99.03 \\
\pm 4.20\end{array}$ & $\begin{array}{l}102.37 \\
\pm 4.45 \\
\end{array}$ \\
\hline
\end{tabular}




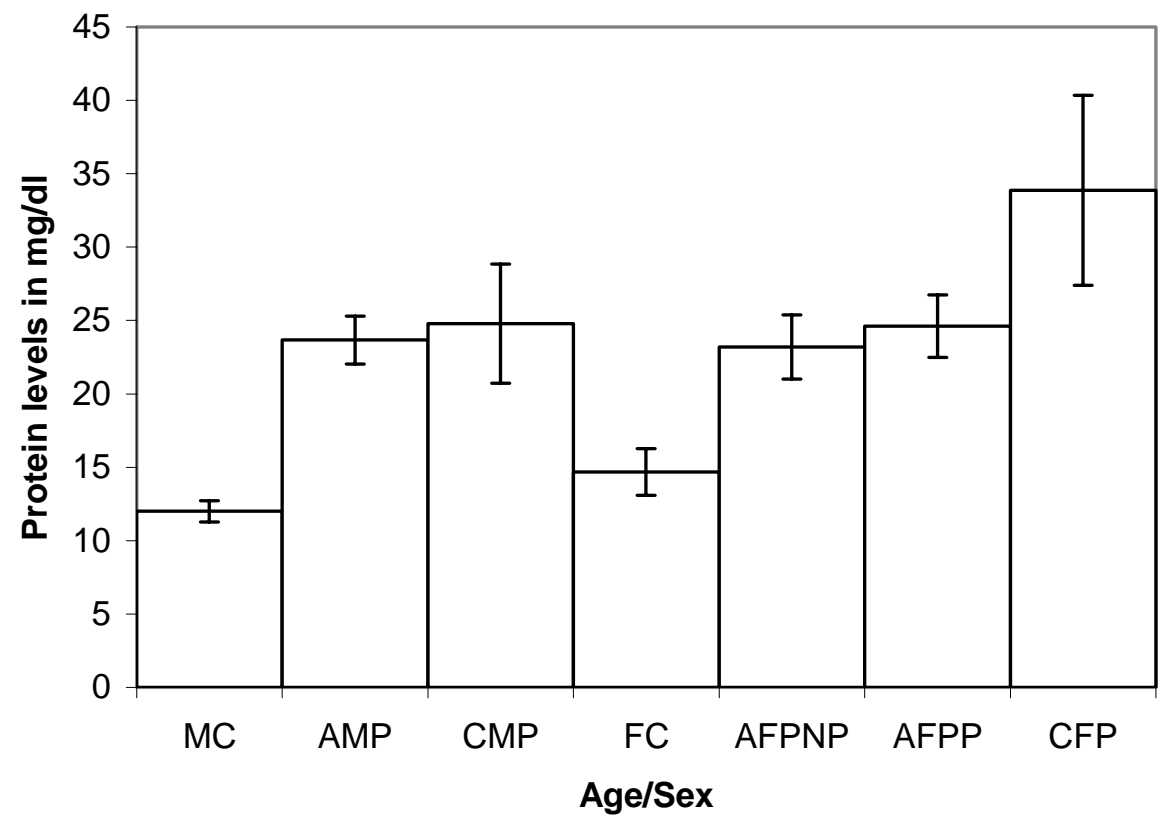

Figure 1. Urinary protein levels in malaria patients and malaria free individuals.

Amounts of protein in early morning urine of 169 malaria patients and 58 controls are compared. Each value on the $\mathrm{Y}$-axis is a mean for each group. The error bars indicate \pm standard error of mean $( \pm \mathrm{SEM})$. $\mathrm{MC}=$ Male controls, $\mathrm{CMP}=$ Children male patients, $\mathrm{AMP}=$ Adult male patients, $\mathrm{FC}=$ Female controls, $\mathrm{CFP}=$ Children female patients, AFPP $=$ Adult female patients - pregnant, AFPNP $=$ Adult female patients - nonpregnant. One-way analysis of variance showed significant difference between the amounts of protein in the urine of malaria patients and those of the controls, $p<0.05$. Similarly, the amount of protein in the urine of CFP is significantly different from that of all the others.

\section{Discussion}

Analysis of data obtained showed excessive excretion of protein in urine of malaria patients of both sexes and among ages 2-15 and ages 16 and above. High level of proteinuria, a characteristic feature of renal dysfunction (Rui-mei, 1998) was recorded in an average of $69.5 \%$ of the total cases studied. This is relatively high when compared to the earlier record of 52\% (Ogbadoyi and Tembeng, 1999). This is suggestive of increasing prevalence of malaria associated renal dysfunction in Minna. The same may be true in other parts of the country. A multi-centre study in the country is important to establish this.

Higher level of proteinuria was noted in ages 2-15 compared to ages 16 and above and this was highest in females aged 2-15 suggesting that children are more prone to malaria associated kidney dysfunction than adults. Our findings are in agreement with those of Weber et al (1999) who made similar observation in a study of renal involvement in Gambian children with malaria.

Females aged 16 and above also had higher proteinuria levels than their male counterparts, which suggests gender influence as speculated in earlier related studies (Ogbadoyi and Tembeng, 1999). Such variations could be a consequence of the anatomical composition of females that predisposes them to urinary and genital tract infections that could likely contribute to such relatively large increase in the level of proteinuria (Abdurahaman et al 1983). Vaginal discharges could also be a factor that contributes to high proteinuria especially in adult females and pregnant women that are prone to these infections (genital tract infection and vaginal discharges). Asymptomatic bacteruria may also have contributed to the high level of proteinuria recorded.

Proteinuria as an indication of renal dysfunction should be taken with great caution. Apparently healthy individuals especially children and adolescence excretes small amounts of protein without demonstrable renal disease, a condition known as orthostatic proteinuria (Edward and Bouchier, 1991). 
Table 2. Analysis of serum electrolytes in malaria patients

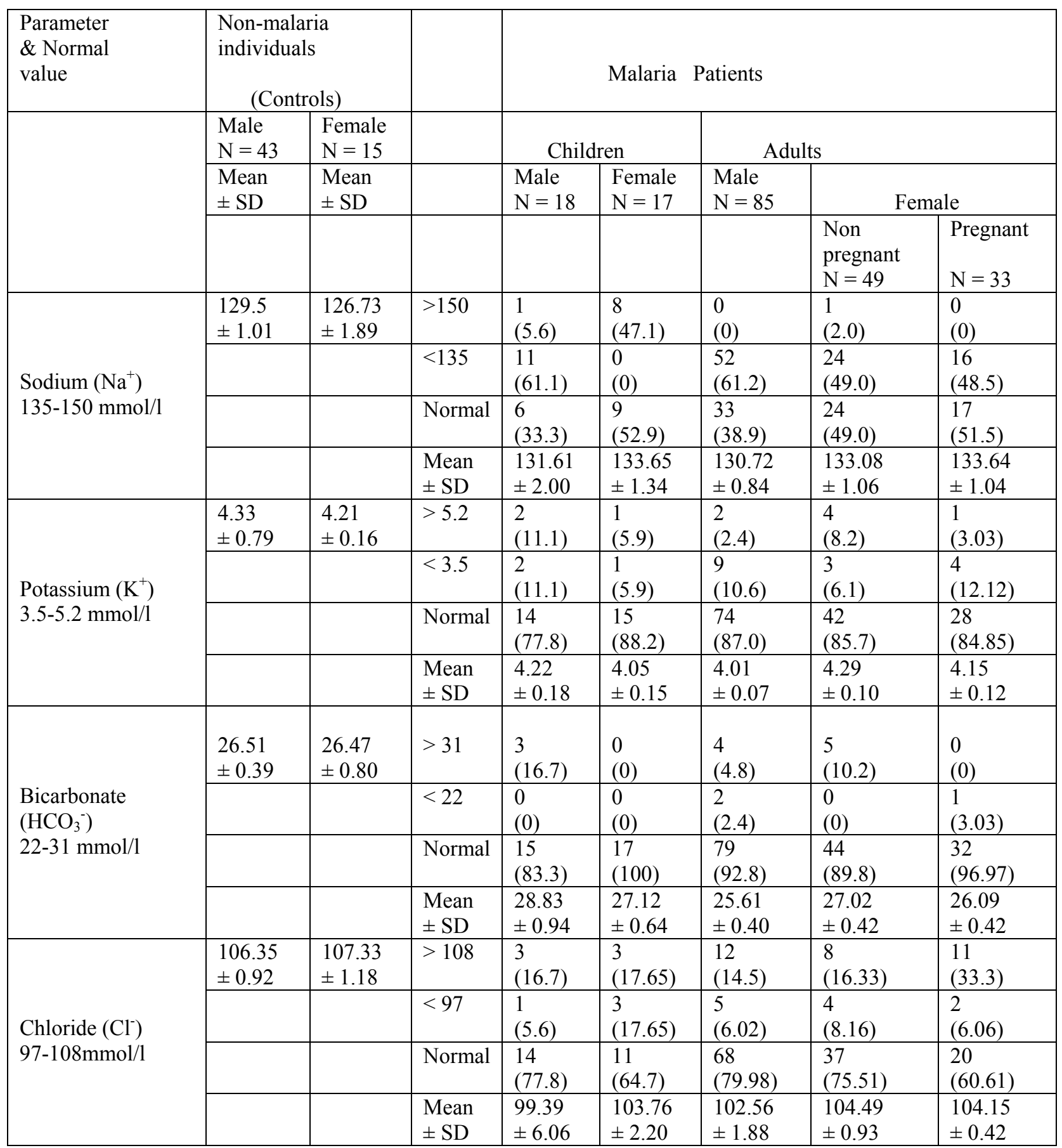

The table shows the normal ranges of the parameters measured, the number of patients and the percentage the number represents, that have values greater or lower than the normal ranges. Values for the controls are also shown. Mean value \pm standard deviation of each parameter is indicated for each group - Controls (male and female), Patients (children - male and female, adults - male and female (pregnant and nonpregnant). $>=$ greater than normal value, $<=$ less than normal value, $\pm \mathrm{SD}=$ standard deviation, numbers in bracket $=$ percentage of number of patients. 
In healthy kidneys, proteins are normally completely filtered from the bloodstream and then reabsorbed, allowing no protein or only small amounts of protein into the urine. Therefore, persistent presence of considerable amounts of protein in the urine is a useful indicator of a form of kidney disease. Therefore, that the amounts of protein in the urine of malaria patients were more than twice the amounts in non-malarial individuals is indicative of some level of renal dysfunction. That this is attributable to malaria is the positive correlation between proteinuria and level of parasitaemia. It will be very useful to measure the amounts of protein in urine after treatment to ascertain if the elevated levels are due to malaria alone. It was difficult to do this in the present study because all the patients were outpatients.

The elevated serum urea levels in female patients, which differed significantly from the nonmalaria individuals, may be primarily due to factors other than malaria as there was no positive correlation between parasitaemia and urea levels. Falciparum malaria is not known to be associated with remarkable disturbance in electrolyte balance (Naqvi et al., 2003). This probably explains why we have been unable to show electrolyte levels in most of the patients that significantly differed from those of the controls. However, sodium, potassium, and bicarbonate showed significant difference in some cases but not in others.

The observed evidence of impairment of renal function in malaria is very important because Nigeria is an endemic country and more so when quite a large number of the population still do not have access to hospital treatment. Even in urban areas where there are hospitals most patients report at hospitals only when self-medications have failed. There is therefore the potential danger of widespread acute renal failure, which may in some cases progress to chronic kidney disease, and the attendant mortality. It is therefore recommended that constant re-evaluation of the incidence and prevalence is done, preferably a country wide study, in order to establish the true picture of the incidence and prevalence of malaria associated kidney dysfunction in Nigeria. This is especially important in children, as malaria is recognized as one of the causes of acute renal failure in children in developing countries (Radhakrishnan and Kiryluk, 2006). Patients who report at hospitals for treatment should be subjected to routine kidney function tests to rule out renal impairment, especially in all cases of severe malaria, as early diagnosis will significantly reduce mortality rate.

\section{Conclusion}

It is concluded that there is a form of renal impairment associated with malaria in Minna, Nigeria, the incidence being higher in females than in males, and among the females, it occurs more in ages 2-15 than in ages 16 and above.

\section{Acknowledgements}

We are grateful to the laboratory staff of the General Hospital, Minna, and the Federal University of Technology, Minna, Clinic for their assistance in sample collection.

\section{References}

1. Abdurrahman M, Green Wood BM, Drape CC, Edington GM, Narayana PT, Babaoye FA, Mclaren MC (1983a) The role of malaria in childhood nephritic syndrome in Northern Nigeria. East African Medical Journal 60: 467-471.

2. Abdurrahman MB, Onuora CU Babaoya FA, Narayana PT (1983b) Renal failure in children in Northern Nigeria. East African Medical Journal 60: 472-477.

3. Barsoum, RS (2000) Malarial acute renal failure. Journal of American Society of Nephrology 11: $2147-2154$

4. Boonpucknaviq V and Sitprija V: (1979) Renal disease in acute Plasmodium falciparum infection in man. Kidney International 6: 44-54.

5. Cheesbrough M. (1991a). Medical Laboratory Manual for Tropical Countries, University press Cambridge, Great Britain 1:221-251.

6. Cheesbrough M. (1991b) Medical Laboratory Manual for TropicalCountries, University press Cambridge Great Britain 2: 133-160. 
7. Davidson and Henry (1979). Clinical Diagnosis by laboratory method, ELBS New York pp340-500.

8. Dittebrandt, M. (1948). American Journal of Clinical Pathology 18: 439

9. Edwards M.J and Bouchier I.A.D (1991) Davidson Principle and Practice of Medicine ELBS Churchill Living Stone Man Group Ltd Hong Kong. Pp600-745.

10. Houba V. (1979). Immunologic aspects of renal lesions associated with malaria. Kidney International 16: 4-8.

11. Kochar, D.K., Argawal, P., Kochar, S.K., Jain, R., Rawat, N., Pokharm, R.K., Kachawa, S., Srivastava, T. (2003). Hepatocyte dysfunction and hepatic encephalopathy in Plasmodium falciparum malaria. Q Journal of Medicine 96: 505-512

12. Mishra SK, Mohapatra S, Mohanty S, Patel NC, and Mohapatra DN (2002). Acute renal failure in falciparum malaria. Journal, Indian Academy of Clinical Medicine 3: 141-147.

13. Mukherjee AP, White S.L, Lau KS. (1971). Falciparum malaria associated with jaundice: Renal failure and anemia. Transaction of the Royal Society of Tropical Medicine and Hygiene 65: 804-814.

14. Nanda R., Mishra, PK., Das, UK., Rout, SB., Mohapatra, PC., Panda, A: (2004) Evaluating role of oxidative stress in determining the pathogenesis of falciparum malaria induced acute renal failure. Indian Journal of Clinical Biochemistry 19: 93-96

15. Naqvi, R., Ahmad, E., Akhtar, F., Naqvi, A., Rizvi, A. (2003) Outcome in severe acute renal failure associated with malaria. Neph Dial Transplant 18: 1820-1823

16. Nchinda T.C. (1998) Malaria: Areemerging disease in Africa. Emerging Infectious Diseases 4 (3): 1-8

17. Ogbadoyi E.O and Tembeng FC (1999). Proteinuria in malaria patients in Minna, Nigeria. Journal of Potozoology Research 9:49-52.

18. Prakash J., Gupta, A., Kumar, O (1996). Acute renal failure in falciparum malaria: increasing prevalence in some areas of India. Nephrology Dialysis Transplantation 11: 2414-2416

19. Radhakrishnan, J., Kiryluk, K (2006) Acute renal failure outcomes in children and adults. Kidney International 69: 17-19

20. Rees PH, Barr RD, Cordy PE and Voller A (1972). Possible role of malaria in aetiology of the nephritic syndrome in Nairobi. British Journal 2:130-131.

21. Rui - Mei L, Kara AU, Sinniah R. (1998a). In situ analysis of adhesion molecule expression in kidney infected with murine malaria. Journal of Pathology 185: 219-225.

22. Rui-Mei L, Kara AU, And Sinniah R. (1998b). Dysregulation of cytokine expression in tubulointerstitial nephritis associated with murine malaria. Kidney International. 53: 8445-8452.

23. Sheehy, TW. and Reba, RC (1967) Complications of falciparum malaria and their treatment. Annals of Internal Medicine 66: 807-809

24. Sinniah R, Rui - mei L, and Kara Au, 1999. Upregulation of cytokines in glomerulonephritis associated with murine malaria infection. International Journal of Experimental Pathology 80: $87-95$.

25. Sitprija, V (1988) Nephropathy in falciparum malaria. Kidney International 34: 867-877

26. Thomson CM and Connor SJ: (2001). The development of malaria early warning systems for Africa. Trends in Parasitology 17: 438 - 445.

27. Van Velthysen MLF (1996). Glomerulopathy associated with parasitic infections. Parasitology Today 12: $102-107$.

28. Weber MW, Zimmer Mann U, Van Hens Brock MB, Frenkil J, Palmer A, Ehrich JHH, Green Wood BM: (1999) Renal involvement in Gambian Children with cerebral or mild malaria. Tropical Medicine and International Health 4: $350-394$. 